\title{
THE
}

\section{Intranasal Ketamine for Acute Pain}

Robert J. Rocchio

University of Rhode Island

E. Ward

University of Rhode Island, kward@uri.edu

Follow this and additional works at: https://digitalcommons.uri.edu/php_facpubs

The University of Rhode Island Faculty have made this article openly available.

Please let us know how Open Access to this research benefits you.

This is a pre-publication author manuscript of the final, published article.

Terms of Use

This article is made available under the terms and conditions applicable towards Open Access

Policy Articles, as set forth in our Terms of Use.

\section{Citation/Publisher Attribution}

Rocchio, R. K. \& Ward, K. E. Intranasal Ketamine for Acute Pain. Clin. J. Pain, 37(4), 295-300. doi: 10.1097/ AJP.0000000000000918

Available at: http://dx.doi.org/10.1097/AJP.0000000000000918 


\section{REVIEW ARTICLE}

\section{Intranasal Ketamine for Acute Pain}

Robert J. Rocchio ${ }^{1}$, Kristina E. Ward ${ }^{1 *}$

University of Rhode Island, Department of Pharmacy Practice ${ }^{1}$

*Corresponding Author: Kristina E. Ward, Clinical Professor and Vice Chair of Pharmacy Practice, University of Rhode Island, 7 Greenhouse Road, Suite 295J, Kingston, RI 02881, Office: (401) 8747484; E-mail: kward@uri.edu

Financial Support: None

Running Head: Intranasal ketamine for acute pain.

Manuscript Word Count: 3,865 


\begin{abstract}
Objectives

To review current evidence regarding the off-label use of intranasal ketamine for acute pain presenting in the setting of the emergency department, and secondary to pediatric limb injuries, renal colic, digital nerve block, and migraines.

$\underline{\text { Results }}$
\end{abstract}

In all five indications reviewed, ketamine demonstrated efficacy in reducing pain. However, when compared to other agents, ketamine did not demonstrate superiority over opioids in pediatric limb injuries or renal colic and was not as efficacious as standard therapy for migraine relief.

Ketamine was also associated with a greater incidence of transient adverse reactions, such as dizziness, bitter aftertaste, fatigue, and vomiting than opioid therapies.

\title{
$\underline{\text { Discussion }}$
}

The current body of evidence is insufficient to support the use of intranasal ketamine over other standard therapies for acute pain. However, current evidence can be used when developing dosing strategies, preparing for adverse reactions, and generating hypotheses for future, more robust research. Keywords: Intranasal ketamine, acute pain, analgesia, emergency department 


\section{Introduction}

Between 2010 and 2017, opioids prescribed in the United States, in proportion to the population, has decreased by $12.8 \% .{ }^{1}$ The downward trend may indicate an increased responsibility and burden on prescribers to combat the current opioid epidemic; especially since prescribed opioids are involved in $36 \%$ of all opioid overdose-related deaths. ${ }^{1}$

Providing analgesic treatment for patients experiencing pain is important, despite the backlash against opioids. However, judgment of whether or not to use opioid therapy can be difficult. In busy settings, such as the emergency department (ED), providers have to quickly determine whether a patient's pain warrants opioid-induced analgesia or treatment with prescription strength non-steroidal anti-inflammatory drugs (NSAIDs). Other non-opioid medications with powerful analgesic effects may be an attractive option for providers.

Profound analgesic and anesthetic properties of phenylcyclidine (PCP), also known as "Angel Dust", prompted scientific investigation into phenylcyclidine derivatives. Researchers sought a molecule that would retain its desired properties, sans its psychotomimetic effects. An early derivative produced in the mid-1960's was CI-581, which later became known as ketamine. ${ }^{2}$ Evidence presented below explores research related to the intranasal form of ketamine and acute pain.

\section{Definition of Acute Pain}

A consensus report on management of acute pain, put forth by American Academy of Pain Medicine, defines acute pain using four characteristics: existence of an event responsible for pain occurrence, sudden onset, temporary duration, and potential ability to develop into other pathological conditions. ${ }^{3}$

\section{$\underline{\text { Ketamine Pharmacology and Pharmacokinetics }}$}

Ketamine is a racemic mixture of $(\mathrm{S})$ - and $(\mathrm{R})$-ketamine. Both enantiomers are non-competitive antagonists of the N-methyl-D-aspartate (NMDA) receptor and interact with other receptors, such as $\mu$ opioid receptors, monoaminergic receptors, muscarinic receptors, and $\gamma$-aminobutyric acid (GABA) 
receptors. ${ }^{4}$ Inhibition of NMDA receptors and activation of opioid and GABA receptors inhibit neuronal cell signaling, resulting in termination of pain transmission. However, activation of monoaminergic receptors is associated with inhibitory or excitatory effects on neuronal cells involved in pain transmission, depending on the specific receptor activated. ${ }^{5}$ The (S)-ketamine enantiomer, otherwise known as esketamine, has a fourfold higher affinity to the NMDA receptor than (R)ketamine..$^{6,7}$

Ketamine retained the analgesic and anesthetic properties of phenycyclidine. However, psychomimetic and psychodysleptic effects still remain. ${ }^{2-4}$ At higher doses, ketamine produces dissociative anesthesia; a state in which a patient cannot respond to external stimuli, despite maintaining relatively normal respiratory and cardiovascular function. Its mechanism producing dissociation is not well documented in current literature; however, ketamine's selective inhibition of the brain's limbic sensory association pathways is speculated as the cause. ${ }^{6}$

Patients report hallucinations, confusion, and other non-specific dissociative symptoms upon awaking from ketamine-induced anesthesia. Called emergence reactions, their occurrence has limited ketamine's use as an anesthetic and analgesic agent., 3,4

When administered intranasally, ketamine's bioavailability is $45-50 \%$. Once in circulation, ketamine undergoes $\mathrm{N}$-demethylation by cytochrome P-450 3A4 to the active metabolite, norketamine, which is reported to have only one-third of the anesthetic properties of ketamine. Half-life of ketamine is two to four hours in adults and approximately 1.5 hours in children. Half-life of norketamine is 12 hours. $^{7}$

\section{Ketamine's Role in the ED for Acute Pain}

As a non-opioid analgesic, ketamine offers pain relief to patients with a known history of opioid abuse and misuse, and to patients who may not tolerate opioid side effects and adverse reactions. Additionally, intranasal ketamine's ease of administration could allow medical staff to quickly treat a patient's pain without the need to locate intravenous access. These properties position intranasal 
ketamine as a useful analgesic in the ED, provided it is efficacious in reducing pain. A systematic review $^{8}$ identified ten studies that evaluated intranasal ketamine and intranasal esketamine's efficacy in treating acute pain in the ED. Studies consisted of both adult and pediatric patient populations. Out of ten included studies, four were randomized controlled trials, ${ }^{9-12}$ four were observational studies, ${ }^{13-16}$ one was a nonrandomized controlled trial, ${ }^{17}$ and the last was a case series. ${ }^{18}$ Seven of the studies are referenced in additional detail in the sections below. ${ }^{9,11-16}$ All ten studies found ketamine to be effective in reducing pain and the results of each are summarized in Table 1.9-18

Authors highlighted the need for additional randomized, controlled trials to measure efficacy of ketamine for treating acute pain in adults. Currently, only two observational studies ${ }^{14,16}$ have evaluated intranasal ketamine's ability to reduce pain for adults presenting to the ED. Dosing strategies for both trials are listed in Table 2. The two studies are useful as references for adverse reactions and dosing for future research, but do not offer clinically meaningful results. Additional evidence is necessary to establish intranasal ketamine's efficacy for reducing pain in adults before its use can be more widely recommended.

$\underline{\text { Pediatric Limb Injuries }}$

Children presenting to the ED, especially those under two years of age, are more likely to be under-treated with opioid analgesic medication than adults. ${ }^{19}$ Provider apprehension regarding respiratory depression or risk of a child developing opioid dependence have been reported as drivers of analgesic medication underuse. ${ }^{19}$ Unlike opioids, ketamine is not commonly associated with respiratory depression. Decreased risk of respiratory depression garners attention towards its use in pediatric patients, since opioid-induced respiratory depression may have fatal consequences if undetected. In a quasi-experiment, ${ }^{15}$ effectiveness of intranasal ketamine for reducing pain in 28 children between 3 to 13 years old presenting to the ED with painful limb injuries was evaluated. Intranasal ketamine was initially dosed at $0.85 \mathrm{mg} / \mathrm{kg}$ with an additional dose 15 minutes after the first at 0.5 $\mathrm{mg} / \mathrm{kg}$ if pain control was inadequate, despite an initial dose of $0.75 \mathrm{mg} / \mathrm{kg}$ specified in study methods. 
The second dose was provided to patients at provider discretion. Primary outcome was pain reported on a Faces Pain Scale - Revised (FPS-R) for children ages 3 to 6 years old and a $100 \mathrm{~mm}$ visual analog score (VAS) for children who were 7 to 13 years old 30 minutes after the initial administration of intranasal ketamine. No patients were assigned to a control. Ketamine was effective in reducing pain from limb injuries on both the FPS-R and VAS 30 minutes after initial administration. Mean baseline pain, taken before ketamine administration was $74.5 \mathrm{~mm}$ (interquartile range (IQR) $=60$ to $85 \mathrm{~mm}$ ), while pain 30 minutes after administration was $30 \mathrm{~mm}(\mathrm{IQR}=12$ to $51.5 \mathrm{~mm}, \mathrm{p}<0.001)$. Average total ketamine dose was $1 \mathrm{mg} / \mathrm{kg}$. The study is limited by its small sample size, use of two different scales for pain measurement, and lack of a control group. ${ }^{15}$ Since effects of intranasal ketamine were not compared to control, the dosing strategy outlined in the study methods was later used in two randomized, controlled trials to compare intranasal ketamine to intranasal fentanyl for limb pain..$^{9,12}$

One of the two randomized, controlled trials enrolled children that were between 3 and 13 years of age, ${ }^{9}$ while the other enrolled older children, from 4 to 17 years of age. ${ }^{12}$ Both trials compared one dose $1 \mathrm{mg} / \mathrm{kg}$ of ketamine to $1.5 \mathrm{mcg} / \mathrm{kg}$ of fentanyl. Primary outcomes were rates of adverse reactions within 60 minutes after ketamine administration for the trial that enrolled older children ${ }^{9}$ and the change from baseline for pain recorded 30 minutes after administration in the trial enrolling a younger population. ${ }^{12}$ Pain at baseline and at 20 and 60 minutes after medication administration was also measured using VAS in the study enrolling older children. ${ }^{9}$

The study of older children enrolled 87 participants. Frequency of adverse effects was 2.2 times greater for children receiving ketamine versus fentanyl. All adverse effects, summarized in Table 3, were transient and mild. The most common adverse effects reported in patients who received ketamine were bad taste in mouth, dizziness, tiredness and drowsiness. Absolute risk differences for adverse effect rate when compared to fentanyl were significant for bad taste and dizziness, but not tiredness nor drowsiness (risk difference $(\mathrm{RD})=68 \%, 95 \% \mathrm{CI}, 53$ to $84 \%$; RD $=59 \%$; 95\% CI, 41 to $76 \% ; \mathrm{RD}=10 \% ; 95 \% \mathrm{CI},-11 \%$ to $31 \%$; and $\mathrm{RD}=7 \% ; 95 \% \mathrm{CI},-6$ to $21 \%$, respectively). Additionally, 
intranasal ketamine was found to be as effective as intranasal fentanyl in reducing pain. No significant difference in pain reduction between either agent was determined in the trial enrolling older children at 20- or 60-minutes using VAS (mean difference $(\mathrm{MD})=9 \mathrm{~mm} ; 95 \%$ confidence interval $(\mathrm{CI}),-5$ to 23 $\mathrm{mm}$ and $\mathrm{MD}=-2 \mathrm{~mm} ; 95 \% \mathrm{CI},-16$ to $13 \mathrm{~mm}$, respectively). Adverse effect reporting was a limitation since drowsiness and tiredness were recorded as two different effects. Children may not articulate their symptoms well enough for investigators to determine if they should be recorded as drowsiness or tiredness. Additionally, children towards the lower end of the included age range may struggle to communicate any adverse effects they experience; especially when under the effect of a psychoactive substance. ${ }^{9}$

The study that enrolled a younger pediatric population evaluated pain at baseline and at 15-, 30-, and 60-minutes post-intervention using VAS for children age 11 to 17 and FPS-R for children age 4 to 10 . The study cohort contained 73 participants; all of whom received $10 \mathrm{mg} / \mathrm{kg}$ of ibuprofen preintervention. No significant difference in pain score reductions was found between the ketamine and fentanyl groups at 15, 30 or 60 minutes post-intervention (median difference $(\mathrm{MedD})=0 \mathrm{~mm} ; 95 \% \mathrm{CI}$, -20 to $20 \mathrm{~mm} ; \mathrm{MedD}=5 \mathrm{~mm} ; 95 \% \mathrm{CI},-10$ to $20 \mathrm{~mm}$; and $\mathrm{MedD}=0 \mathrm{~mm} ; 95 \% \mathrm{CI},-13$ to $13 \mathrm{~mm}$, respectively) or in proportion of patients with a decreased VAS or FPS-R greater than or equal to 20 $\mathrm{mm}(\mathrm{MedD}=1 \mathrm{~mm} ; 95 \% \mathrm{CI},-20$ to $22 ; \mathrm{MedD}=3 ; 95 \% \mathrm{CI},-16$ to 22 ; and $\mathrm{MedD}=9 ; 95 \% \mathrm{CI},-8$ to 27, respectively). Participants who received ketamine reported a greater number of adverse effects than those in the fentanyl group ( 78 versus 40 , respectively). The most commonly reported adverse effects for patients who received ketamine were bad taste in mouth, drowsiness, and dizziness. Trial limitations include use of ibuprofen before administration of fentanyl or ketamine, which makes it impossible to determine what amount of pain reduction is attributed to either fentanyl or ketamine alone. Additionally, patient pain was recorded through two different scales. Data was combined from both scales to achieve adequate power for the study's analysis. Differences in responses between scales reduced the study's internal validity. ${ }^{12}$ 
An additional study, PRIME, ${ }^{20}$ was a randomized, controlled, non-inferiority trial comparing intranasal ketamine and intranasal fentanyl. Investigators stated that previous dosing strategies in other trials evaluating intranasal ketamine were too conservative but did not describe how their dosing protocol was developed. Ketamine was dosed at $1.5 \mathrm{mg} / \mathrm{kg}$ while fentanyl was dosed at $2 \mathrm{mcg} / \mathrm{kg}$. The study cohort consisted of 90 participants who were between 8 to 17 years of age. Primary outcome was reduction in pain from baseline to 30 minutes post-intervention. Pain scores were recorded using VAS. Non-inferiority margin was set to $10 \mathrm{~mm}$, which is validated as the minimally important difference in VAS in children.

Intranasal ketamine was declared non-inferior to intranasal fentanyl. At 15-, 30-, and 60minutes post-intervention, no significant difference in pain reduction from baseline was found between the ketamine and fentanyl groups $(\mathrm{MD}=0.93 ; 95 \% \mathrm{CI},-6.09$ to $7.96 ; \mathrm{MD}=1.26 ; 95 \% \mathrm{CI},-6.19$ to 8.71; and $\mathrm{MD}=1.30 ; 95 \% \mathrm{CI},-7.36$ to 9.95 , respectively). All adverse effects reported were mild and transient and were found at higher rates in the ketamine group (relative risk $(\mathrm{RR})=2.5 ; 95 \% \mathrm{CI}, 1.5$ to 4.0). The most common adverse effects for those in the ketamine group were dizziness, unpleasant taste, and drowsiness. Study limitations include a maximum dose supplied of $100 \mathrm{mcg}$ of fentanyl and $100 \mathrm{mg}$ of ketamine. Patients who weighed greater than $50 \mathrm{~kg}$ or $67 \mathrm{~kg}$ were unable to receive a full dose of fentanyl or ketamine, respectively. However, investigators attested that differences in pain reduction between patients who were under-dosed versus those who received a full dose of ketamine or fentanyl were not significant. ${ }^{20}$

Based on the available data in pediatric limb injuries, intranasal ketamine may represent a potential option for providers although quantity and quality of data is limited. Adverse effects seem more common with intranasal ketamine compared to opioid controls, but of potential lesser severity. Nephrolithiasis

Further research analyzed the analgesic effects of intranasal ketamine for specific etiologies of pain. One such etiology, nephrolithiasis, is associated with excruciating pain and occurs in 19\% of men 
and $9 \%$ of women. Renal colic involves uretal passage of the mass. ${ }^{21}$ Pharmacologic agents used in treatment of renal colic focus on providing pain relief. ${ }^{21-23}$ Medications used include injectable nonsteroidal anti-inflammatory drugs (NSAIDs) and injectable opioids. ${ }^{21}$ Recently, two randomized controlled trials were conducted to determine if intranasal ketamine may be also be an effective analgesic agent for renal colic.

In the first trial, ${ }^{22} 40$ patients were randomized to receive intranasal ketamine or intravenous (IV) morphine upon presentation to the ED with renal colic. Ketamine and morphine were individually dosed for patients using $1 \mathrm{mg} / \mathrm{kg}$ body weight and $0.1 \mathrm{mg} / \mathrm{kg}$ body weight, respectively. Placebo was administered IV or intranasally via the double-dummy technique. Pain experienced by patients was recorded using a VAS determined pre-intervention and at 5-, 10-, and 30-minutes post-intervention. Patients who received ketamine had significantly greater pain at baseline and at 5 minutes after receiving treatment $(\mathrm{MD}=-0.95 \mathrm{~mm} ; 95 \% \mathrm{CI},-1.75$ to $-0.14 \mathrm{~mm}$; and $\mathrm{MD}=-0.79 \mathrm{~mm} ; 95 \% \mathrm{CI},-1.48$ to -0.10 , respectively). However, ketamine closed the initial gap in VAS scores with morphine as it did not demonstrate significant differences in recorded pain at 15- and 30-minutes post-intervention once adjusted for baseline discrepancies $(\mathrm{MD}=-0.36 ; 95 \% \mathrm{CI},-1.08$ to 0.34 ; and $\mathrm{MD}=-0.15 ; 95 \% \mathrm{CI}$, 1.02 to 0.71 , respectively). Limiting the trial, a significant difference in baseline pain between the ketamine and morphine groups was present. Additionally, only $15 \%$ of patients in the morphine group were women, while $40 \%$ of patients in the ketamine group were women. Lastly, trial results are not generalizable to the U.S. population since all 40 subjects were patients presenting to one of two ED's in $\operatorname{Iran}^{22}$

A similar, but larger, study that evaluated efficacy of intranasal ketamine for treating pain secondary to renal occlusion was conducted in 130 patients presenting to the ED for renal colic also in Iran. ${ }^{23}$ However, the comparator differed; $1 \mathrm{mg} / \mathrm{kg}$ of intranasal ketamine was compared to $1 \mathrm{mcg} / \mathrm{kg}$ of intravenous fentanyl. As with the study comparing ketamine to morphine, ${ }^{22}$ blinding was conducted via the double dummy technique. Both intranasal and intravenous placebos consisted of distilled water; 
a limitation, since administration of distilled water via intranasal or IV routes induces pain. Pain was recorded on a VAS scale before medication administration and at 5-, 15-, and 30-minutes posttreatment. Both groups had significant reductions in VAS scores over the 30 -minute interval ( $\mathrm{p}<$ 0.001). Mean reduction in VAS, as well as mean VAS at baseline, and at 5-, 15-, and 30-minutes post treatment were not provided. Average pain reported was greater in the fentanyl group before treatment and at 5-and 15-minutes post-intervention, but no statistical significance for mean difference in pain was provided by the investigators. No significant difference in pain was found between ketamine and fentanyl at 30 minutes $(\mathrm{p}=0.449)$. At conclusion of the 30 -minute interval, $32.3 \%$ of patients in the ketamine and $9.2 \%$ of patients in the fentanyl group required additional analgesic medications $(\mathrm{p}=$ 0.002). ${ }^{23}$ Trial limitations include use of a placebo that directly induced pain, not providing assessment of statistical significance for all outcomes, and not providing baseline characteristics for each treatment arm. Since mean differences in VAS for the time intervals were not reported, not enough information is available to determine clinically meaningful differences in pain. ${ }^{23}$

Data supporting use of intranasal ketamine for renal colic associated with nephrolithiasis is sparse. Assessment of effect on pain control is challenging since only one study presented data for pain control at multiple time points which showed an initial lesser response than the intravenous, opioid comparator. Use of intranasal ketamine for renal colic seems premature.

\section{$\underline{\text { Digital Nerve Block }}$}

To address another specific cause of pain, digital nerve block with injectable anesthetic medications is used in preparation for certain procedures, such as toenail removal, removal of foreign objects, and drainage of digital infections. ${ }^{11,24,25}$ However, the actual injection procedure is reported to be painful. One study evaluated application of ice to reduce pain from digital nerve block before administration of the anesthetic. Ice was effective in reducing needle-stick pain, however other pharmacologic agents may be desired for greater pain relief. ${ }^{25}$ 
One study evaluated the use of intranasal ketamine to reduce pain related to digital nerve block in 100 patients. ${ }^{11}$ The study took place in the ED of a 100 bed hospital in Iran. Patients were randomized to receive either $50 \mathrm{mg}$ of intranasal ketamine or a matching volume of intranasal placebo. All adults scheduled to receive digital nerve block were eligible for inclusion. Exclusion criteria included altered mental status, signs of decompensated heart failure, pregnancy, systolic blood pressure greater than $180 \mathrm{mmHg}$ or diastolic blood pressure greater than $80 \mathrm{mmHg}$, and use of a prescription opioid within 24 hours. Patient reported pain was recorded using VAS. Measurements were taken at baseline, immediately after, and 45 minutes after administration of local anesthetic.

Median baseline pain scores were reported as $50 \mathrm{~mm}$ in ketamine treatment group and $49 \mathrm{~mm}$ in placebo group (95\% CI 42.5 to $53 \mathrm{~mm}$ and 47 to $48 \mathrm{~mm}$, respectively; $\mathrm{p}=0.19$ ). Median pain scores taken immediately after digital nerve block were $28.5 \mathrm{~mm}$ in the ketamine treated group and $47.5 \mathrm{~mm}$ in the placebo treated group (95\% CI 24 to $32 \mathrm{~mm}$ and 40 to $52 \mathrm{~mm}$, respectively; $\mathrm{p}<0.001)$. Lastly, median pain scores 45 minutes after performing the nerve block were $21.5 \mathrm{~mm}$ in the treatment arm and $43.5 \mathrm{~mm}$ in the placebo arm (95\% CI 17 to $25 \mathrm{~mm}$ and 32 to $42 \mathrm{~mm}$, respectively; $\mathrm{p}<0.001)$.

Ketamine was superior to placebo for alleviating pain associated with digital nerve block. However, pain induced by digital nerve block versus pain secondary to the original injury was not differentiated. Patients only reported one pain score at three different intervals for their overall perception of pain. Therefore, conclusions can only be drawn regarding the reduction in total pain for patients who undergo a digital nerve block procedure. Other study limitations include a small sample size from a singular hospital in Iran and a lack of blinding for those administering the intranasal medication. The study results are not generalizable to a broader population. ${ }^{11}$ Future studies with larger and more diverse populations are warranted to establish whether intranasal ketamine use during digital nerve block represents a clinical improvement over current methods of pain control. $\underline{\text { Migraines }}$ 
Finally, research has evaluated intranasal ketamine's potential role for treating acute pain in patients suffering from episodes of migraine with auras. Two small, randomized, controlled trials evaluated the efficacy of intranasal ketamine for migraine relief. ${ }^{26,27}$ Inclusion and exclusion criteria for both studies are summarized in Table 4.

The first trial compared the efficacy of $25 \mathrm{mg}$ of intranasal ketamine versus $2 \mathrm{mg}$ of intranasal midazolam for pain secondary to migraines with aura. Midazolam was chosen as a control to maintain blinding, since both ketamine and midazolam have psychotropic effects. However, midazolam is not a standard treatment for migraines with aura and was not expected to provide relief. The studied cohort consisted of 18 individuals. Recruited subjects were asked to complete and submit a survey for 6 migraine with aura episodes that they had experienced over a two-year study window. All symptoms recorded in the survey were ranked from 0 to 3, with 3 being the most severe and 0 being no symptoms. Subjects self-administered their nasal spray at symptom onset for three of six episodes. Subjects were not dispensed dosages of intranasal therapy that could be used for the remaining 3 episodes. Use of supplementary over-the-counter analgesics or prescription prophylaxis therapy was permitted for all patients throughout the study. Results indicated that ketamine significantly reduced severity of migraine with aura $(p=0.032)$, however midazolam failed to demonstrate any effect on migraine severity $(\mathrm{p}=0.2)$.

The study was small and its dataset was incomplete, since 10 out of the 18 subjects had missing data. Additionally, subjects may have saved their intranasal medication for more severe migraine episodes, which would result in greater baseline severity in the intranasal treatment arm. Lastly, subjects were asked to record their migraine experience during an exacerbation. Patients who had experienced especially severe migraine episodes may have been unable to complete the survey, which would exclude the worst migraine cases from the analysis. Patients who completed the survey were doing so under the effect of a psychoactive agent, which also could decrease response. ${ }^{26}$ 
The second trial ${ }^{27}$ included patients with any type of primary migraine. A total of 53 subjects were enrolled and consisted of patients presenting to the ED with migraines warranting treatment with parenteral therapy. Patients were randomized to receive either standard therapy $(25 \mathrm{mg}$ of diphenhydramine and $10 \mathrm{mg}$ of metoclopramide in $1000 \mathrm{~mL}$ normal saline IV) plus up to two administrations of saline nasal spray or placebo standard therapy $(1000 \mathrm{~mL}$ normal saline IV without diphenhydramine or metoclopramide) plus up to two administrations of ketamine nasal spray. First dose of intranasal ketamine was $0.75 \mathrm{mg} / \mathrm{kg}(\max 75 \mathrm{mg})$ and second dose was $0.25 \mathrm{mg} / \mathrm{kg}(\max 25$ mg). Primary outcome was pain 30 minutes after medication administration, which was reported via VAS.

Statistical analysis failed to demonstrate any difference between ketamine and standard therapy in VAS scores for pain 30 minutes after administration of therapy or on a verbal numerical rating scale for pain at $\mathrm{ED}$ discharge $(\mathrm{MD}=6.8 ; 95 \% \mathrm{CI},-5.8$ to 19.4$)$. Study limitations include a lack of blinding for providers who prescribed and administered ketamine or standard therapy, a small sample size, and providers were permitted to administer $30 \mathrm{mg}$ of IV ketorolac or $10 \mathrm{mg}$ of IV dexamethasone as additional therapy to the control group. Ketorolac was provided to 21 out of 26 patients, while dexamethasone was provided to 7 out of 26 patients in the control group. ${ }^{27}$

Overall, no substantial evidence supports intranasal ketamine's role in migraine relief. Other evidence evaluating IV ketamine has also demonstrated ineffective treatment of pain related to migraines. A randomized, controlled trial found no significant difference between IV ketamine and IV saline placebo for migraine relief. ${ }^{28}$ Based on current literature, ketamine should not be used in place of standard therapy for the treatment of migraines.

\section{$\underline{\text { Discussion }}$}

Intranasal ketamine has demonstrated efficacy in reducing acute pain for patients at home and who are presenting to the ED. Compared to opioids, ketamine demonstrates non-significant differences in analgesic efficacy, but does demonstrate greater rates of minor and transient adverse effects. 
Dizziness, bitter after-taste, fatigue and vomiting are the most commonly reported adverse effects of ketamine. Overall quantity of evidence supporting intranasal ketamine's use for specific etiologies of pain is insufficient to support its use over other standard therapies but should not preclude its consideration. Intranasal ketamine shows promise for patients who are at risk for opioid use disorder, opioid tolerance, or who are at risk for respiratory depression. Furthermore, practitioners in the ED setting may feel more comfortable administering intranasal ketamine to pediatric patients presenting with severe pain, who are commonly under-treated with opioids. 


\section{References}

1. Schieber LZ, Guy Jr GP, Seth P, et al. Trends and patterns of geographic variation in opioid prescribing practices by state, United States, 2006-2017. JAMA Netw Open. 2019;2:e190665e190665. doi:10.1001/jamanetworkopen.2019.0665.

2. Domino EF, Chodoff P, Corssen G. Pharmacologic Effects of CI-581, A new dissociative anesthetic, in man. Clin Pharmacol Ther. 1965;6:279-291. doi:10.1002/cpt196563279.

3. Tighe P, Buckenmaier III CC, Boezaart AP, et al. Acute pain medicine in the United States: A status report. Pain Med. 2015;16:1806-1826. doi:10.1111/pme.12760.

4. Li L, Vlisides PE. Ketamine: 50 years of modulating the mind. Front Hum Neuroscience. 2016;10:612. https://www.frontiersin.org/article/10.3389/fnhum.2016.00612.

5. Yam MF, Loh YC, Tan CS, et al. General Pathways of Pain Sensation and the Major Neurotransmitters Involved in Pain Regulation. Int J Mol Sci. 2018 Jul 24;19. doi:10.3390/ijms 19082164 .

6. Ketalar (ketamine hydrochloride) [package insert]. Par Pharmaceutical, Inc; Chestnut Ridge (NY): July 2018.

7. Spravato (esketamine) [package insert]. Janssen Pharmaceutical Companies; Titusville (NJ): March 2019.

8. Pakniyat A, Qaribi M, Hezaveh DR, et al. Intranasal ketamine as an analgesic agent for acute pain management in emergency department: A literature review. J Acute Dis. 2019;7:241-246. doi:10.4103/2221-6189.248028.

9. Reynolds SL, Bryant KK, Studnek JR, et al. Randomized controlled feasibility trial of intranasal ketamine compared to intranasal fentanyl for analgesia in children with suspected extremity fractures. Acad Emerg Med. 2017;24:1430-1440. doi:10.1111/acem.13313. 
10. Parvizrad R, Pakniyat A, Malekianzadeh B, et al. Comparing the analgesic effect of intranasal with intravenous ketamine in isolated orthopedic trauma: A randomized clinical trial. Turkish $J$ Emerg Med. 2017;17:99-103. doi:10.1016/j.tjem.2017.05.006.

11. Nejati A, Jalili M, Abbasi S, et al. Intranasal ketamine reduces pain of digital nerve block; a double blind randomized clinical trial. Am J Emerg Med. 2019;37:1622-1626. doi:10.1016/j.ajem.2018.11.026.

12. Graudins A, Meek R, Egerton-Warburton D, et al. The PICHFORK (pain in children fentanyl or ketamine) trial: A randomized controlled trial comparing intranasal ketamine and fentanyl for the relief of moderate to severe pain in children with limb injuries. Ann Emerg Med. 2015;65:248254.e1. Doi:10.1016/j.annemergmed.2014.09.024.

13. Andolfatto G, Willman E, Joo D, et al. Intranasal ketamine for analgesia in the emergency department: A prospective observational series. Acad Emerg Med. 2013;20:1050-1054. doi:10.1111/acem.12229.

14. Yeaman F, Meek R, Egerton-Warburton D, et al. Sub-dissociative-dose intranasal ketamine for moderate to severe pain in adult emergency department patients. Emerg Med Australas. 2014;26:237-242. doi:10.1111/1742-6723.12173.

15. Yeaman F, Oakley E, Meek R, et al. Sub-dissociative dose intranasal ketamine for limb injury pain in children in the emergency department: A pilot study. Emerg Med Australas. 2013;25:161167. doi:10.1111/1742-6723.12059.

16. Shrestha R, Pant S, Shrestha A, et al. Intranasal ketamine for the treatment of patients with acute pain in the emergency department. World J Emerg Med. 2016;7:19-24. doi:10.5847/wjem.j.1920-8642.2016.01.003. 
17. Nielsen BN, Friis SM, Rømsing J, et al. Intranasal sufentanil/ketamine analgesia in children. Pediatr Anesth. 2014;24:170-180. doi:10.1111/pan.12268.

18. Johansson J, Sjöberg J, Nordgren M, et al. Prehospital analgesia using nasal administration of Sketamine - a case series. Scand J Trauma Resusc Emerg Med. 2013;21:38. doi:10.1186/17577241-21-38.

19. Alexander J, Manno M. Underuse of analgesia in very young pediatric patients with isolated painful injuries. Ann Emerg Med. 2003;41:617-622. doi:10.1067/mem.2003.138.

20. Frey TM, Florin TA, Caruso M, et al. Effect of intranasal ketamine vs fentanyl on pain reduction for extremity injuries in children: The PRIME randomized clinical trial. JAMA Pediatr. 2019;173:140-146. doi:10.1001/jamapediatrics.2018.4582.

21. Curhan, GC. Nephrolithiasis. In: Jameson J, Fauci AS, Kasper DL, Hauser SL, Longo DL, Loscalzo J. eds. Harrison's Principles of Internal Medicine, 20e New York, NY: McGraw-Hill. http://accesspharmacy.mhmedical.com.uri.idm.oclc.org/content.aspx?bookid=2129\&sectionid=1 59213747. Accessed September 25, 2019.

22. Farnia MR, Jalali A, Vahidi E, et al. Comparison of intranasal ketamine versus IV morphine in reducing pain in patients with renal colic. Am J Emerg Med. 2017;35:434-437. doi:https://doi.org/10.1016/j.ajem.2016.11.043.

23. Mozafari J, Maleki Verki M, Motamed H, et al. Comparing intranasal ketamine with intravenous fentanyl in reducing pain in patients with renal colic: A double-blind randomized clinical trial. Am J Emerg Med. 2019. doi:10.1016/j.ajem.2019.05.049.

24. Ballo S, Hjelseng T, Tangen LF, et al. The influence of injected volume on discomfort during administration of digital block. J Hand Surg Asian Pac Vol. 2016 Oct;21:369-73. doi:10.1142/S2424835516500363. 
25. Hayward SC, Landorf KB, Redmond AC. Ice reduces needle-stick pain associated with a digital nerve block of the hallux. Foot. 2006;16:145-148.

doi:https://doi.org/10.1016/j.foot.2006.04.001.

26. Afridi SK, Giffin NJ, Kaube H, et al. A randomized controlled trial of intranasal ketamine in migraine with prolonged aura. Neurology. 2013;80:642 LP - 647. doi:10.1212/WNL.0b013e3182824e66.

27. Benish T, Villalobos D, Love S, et al. The THINK (treatment of headache with intranasal ketamine) trial: A randomized controlled trial comparing intranasal ketamine with intravenous metoclopramide. J Emerg Med. 2019;56:248-257.e1. Doi:10.1016/j.jemermed.2018.12.007.

28. Etchison AR, Bos L, Ray M, et al. Low-dose ketamine does not improve migraine in the emergency department: A randomized placebo-controlled trial. West J Emerg Med. 2018;19:952-960. doi:10.5811/westjem.2018.8.37875. 
Table 1. Summary of Publications Regarding Use of Intranasal Ketamine in the $\mathrm{ED}^{7}$

\begin{tabular}{|c|c|c|c|}
\hline Study & Type & Comparator & Results \\
\hline $\begin{array}{l}\text { Graudins et } \\
\mathrm{al}^{11}\end{array}$ & $\mathrm{RCT}^{\dagger}$ & $\begin{array}{l}\text { Intranasal } \\
\text { fentanyl }\end{array}$ & $\begin{array}{l}\text { - } \mathrm{N}=80^{\dagger} \\
\text { - Mean difference in pain reduction for children presenting } \\
\text { to the } \mathrm{ED} \text { with limb injuries was non-significant after ad- } \\
\text { ministration of ketamine or fentanyl } \\
\text { - } 15 \text { minutes after: } \mathrm{MD}=5 \mathrm{~mm}, 95 \% \mathrm{CI}=-10 \text { to } 20 \\
\text { - } 30 \text { minutes after: } \mathrm{MD}=0 \mathrm{~mm}, 95 \% \mathrm{CI}=-20 \text { to } 20 \\
\text { - } 60 \text { minutes after: } \mathrm{MD}=0 \mathrm{~mm}, 95 \% \mathrm{CI}=-13 \text { to } 13\end{array}$ \\
\hline $\begin{array}{l}\text { Nejati et } \\
\mathrm{al}^{10}\end{array}$ & RCT & Placebo & $\begin{array}{l}\text { - } \mathrm{N}=100 \\
\text { - Median pain scores taken immediately after digital nerve } \\
\text { block were } 28.5 \mathrm{~mm} \text { in the ketamine group and } 47.5 \mathrm{~mm} \\
\text { in the placebo group }(\mathrm{p}<0.001) \text {. } \\
\text { - Median pain scores } 45 \text { minutes after performing the nerve } \\
\text { block were } 21.5 \mathrm{~mm} \text { in the treatment arm and } 43.5 \mathrm{~mm} \text { in } \\
\text { the placebo arm }(\mathrm{p}<0.001) \text {. }\end{array}$ \\
\hline $\begin{array}{l}\text { Reynolds et } \\
\mathrm{al}^{8}\end{array}$ & RCT & $\begin{array}{l}\text { Intranasal } \\
\text { fentanyl }\end{array}$ & $\begin{array}{l}\text { - } \mathrm{N}=87 \\
\text { - } \\
\text { taste in molute risk difference was significant for rate of bad } \\
\text { ness (RD }=59 \% ; 95 \% \text { CI, } 41 \text { to } 76 \% \text { ) } \\
\text { - } \quad \text { No significance was found for rates of tiredness }(\mathrm{RD}= \\
10 \% ; 95 \% \mathrm{CI},-11 \% \text { to } 31 \% \text { ) or drowsiness (RD }=7 \% \text {; } \\
95 \% \mathrm{CI},-6 \text { to } 21 \%)\end{array}$ \\
\hline
\end{tabular}




\begin{tabular}{|c|c|c|c|}
\hline & & & $\begin{array}{l}\text { No significant difference in pain reduction was determined } \\
\text { in pain reduction at } 20 \text { or } 60 \text { minutes }(\mathrm{MD}=9 \mathrm{~mm} ; 95 \% \\
\mathrm{CI},-5 \text { to } 23 ; \mathrm{MD}=-2 \mathrm{~mm} ; 95 \% \mathrm{CI},-16 \text { to } 13 \text {, respec- } \\
\text { tively) }\end{array}$ \\
\hline Parvizrad $^{9}$ & RCT & $\begin{array}{l}\text { Ketamine } \\
\text { IV }\end{array}$ & $\begin{array}{l}\text { - } \mathrm{N}=154 \\
\text { - } 30 \text { minutes post-ketamine administration, mean reported } \\
\text { pain scores were } 31.5 \mathrm{~mm} \text { in the intranasal ketamine group } \\
\text { and } 29.35 \text { in the IV ketamine group }(\mathrm{p}<0.005)\end{array}$ \\
\hline $\begin{array}{l}\text { Nielsen et } \\
\mathrm{al}^{16}\end{array}$ & $\mathrm{NRCT}^{*}$ & None & $\begin{array}{l}\text { - } \mathrm{N}=50 \\
\text { - Median reported pain score for children who underwent } \\
\text { any painful procedure was } 3.1 \mathrm{~mm}(\mathrm{IQR} 2.0-4.9) \text { after ad- } \\
\text { ministration of ketamine/sufentanyl }\end{array}$ \\
\hline $\begin{array}{l}\text { Andolfatto } \\
\text { et a } 1^{12}\end{array}$ & $\mathrm{Obs}^{\circ}{ }^{\circ}$ & None & $\begin{array}{l}\text { - } \mathrm{N}=40 \\
\text { - } 88 \% \text { of patients experienced a reduction in pain }>13 \mathrm{~mm}\end{array}$ \\
\hline $\begin{array}{l}\text { Yeaman et } \\
\text { al }(2013)^{14}\end{array}$ & Obs & None & $\begin{array}{l}\text { - } \mathrm{N}=28 \\
\text { - } \mathrm{Median} \text { pain at enrollment was reduced from } 74.5 \mathrm{~mm} \text { to } \\
30 \mathrm{~mm} \text { at } 30 \text { minutes }(\mathrm{p}<0.001)\end{array}$ \\
\hline $\begin{array}{l}\text { Yeaman et } \\
\text { al }(2014)^{13}\end{array}$ & Obs & None & $\begin{array}{l}\text { - } \mathrm{N}=72 \\
\text { - Ketamine dosed at } 1 \mathrm{mg} / \mathrm{kg} \text { was effective in reducing pain } \\
\text { in } 56 \% \text { of patients }\end{array}$ \\
\hline
\end{tabular}




\begin{tabular}{|c|c|c|c|}
\hline & & & $\begin{array}{l}\text { - } 56 \% \text { of patients reported pain score reductions } \geq 20 \mathrm{~mm} \\
(95 \% \mathrm{CI}, 44.0 \text { to } 66.7)\end{array}$ \\
\hline $\begin{array}{l}\text { Shrestha et } \\
\mathrm{al}^{15}\end{array}$ & Obs & None & $\begin{array}{l}\text { - } \mathrm{N}=39 \\
\text { - } 79 \% \text { of adults patients }(\mathrm{n}=34) \text { experienced pain relief } \\
(>20 \mathrm{~mm} \text { on VAS) } 15 \text { minutes after intranasal ketamine } \\
\text { administration, while } 100 \% \text { of patients experienced pain } \\
\text { relief after } 30 \text { and } 60 \text { minutes. }\end{array}$ \\
\hline $\begin{array}{l}\text { Johansson } \\
\text { et } \mathrm{al}^{17}\end{array}$ & $\mathrm{CS}^{\perp}$ & None & $\begin{array}{l}\text { - } \mathrm{N}=34 \\
\text { - } \text { Evaluated reduction in pain after administration of intrana- } \\
\text { sal esketamine } \\
\text { - } \text { Pain scores decreased more than } 20 \mathrm{~mm} 15 \text { minutes after } \\
\text { ketamine administration in } 80 \% \text { of patients } \\
\text { - Median pain reduction at } 30 \text { minutes was } 50 \mathrm{~mm} \text { (inter- } \\
\text { quartile range }=40 \text { to } 70 \text { ) }\end{array}$ \\
\hline
\end{tabular}

Differences in pain presented as reduction in VAS reported pain score, unless otherwise noted

${ }^{\dagger}$ Randomized controlled trial (RCT)

${ }^{\dagger}$ Number of patients included in study analysis

\#Non-randomized clinical trial (NRCT)

${ }^{\circ}$ Observational study (Obs)

${ }^{>}$Case Series (CS) 
Table 2: Dosing Strategies for Studies Evaluating Ketamine in Acute Adult Pain in the ED

\begin{tabular}{|c|c|}
\hline Study & Dosing Strategy \\
\hline $\begin{array}{l}\text { Yeaman et al } \\
(2014)^{13}\end{array}$ & $\begin{array}{l}\text { - First } 6 \text { months of this study: } 0.7 \mathrm{mg} / \mathrm{kg} \text { dose of ketamine. } \\
\text { - Second } 6 \text { months of study: } 1.0 \mathrm{mg} / \mathrm{kg} \text { of ketamine } \\
\text { - Additional intranasal doses of } 0.5 \mathrm{mg} / \mathrm{kg} \text { were provided over the course of the } \\
\text { study }^{\dagger}\end{array}$ \\
\hline $\begin{array}{l}\text { Shrestha et al } \\
(2016)^{15}\end{array}$ & $\begin{array}{l}\text { - Initial dose: } 0.7 \mathrm{mg} / \mathrm{kg} \\
\text { - Optional: additional } 0.3 \mathrm{mg} / \mathrm{kg} \text { dose } 15 \text { minutes after the initial administra- } \\
\text { tion }\end{array}$ \\
\hline
\end{tabular}

${ }^{t}$ The trial investigators did not provide information regarding why and when the additional doses of intranasal ketamine $0.5 \mathrm{mg} / \mathrm{kg}$ were administered.

The additional $0.3 \mathrm{mg} / \mathrm{kg}$ dose was provided upon patient request. 
Table 3: Rates of Adverse Effects within 60 Minutes After Administration of Intranasal Ketamine ${ }^{8}$

\begin{tabular}{|l|l|}
\hline Adverse Effect & Frequency \\
\hline Bad taste in mouth & \\
\hline Dizziness & $90 \%$ \\
\hline Sleepiness & $73 \%$ \\
\hline Drowsiness & $46 \%$ \\
\hline Itchy nose & $15 \%$ \\
\hline Visual disturbance & $24 \%$ \\
\hline Nausea & $10 \%$ \\
\hline
\end{tabular}


Table 4: Inclusion and Exclusion Criteria for Studies Evaluating Migraine Relief

\begin{tabular}{|c|c|c|}
\hline Study & Inclusion Criteria & Exclusion Criteria \\
\hline $\begin{array}{l}\text { Benish et al } \\
(2019)^{26}\end{array}$ & $\begin{array}{l}\text { - } 18-65 \text { years old } \\
\text { - Pain between 5-10 } \\
\text { on a 0-10 verbal re- } \\
\text { sponse scale } \\
\text { - Primary headache } \\
\text { - Syndrome } \\
\text { - Symptoms warrant } \\
\text { parenteral analgesia }\end{array}$ & $\begin{array}{l}\text { - Weight }<45 \mathrm{~kg} \text { or }>115 \mathrm{~kg} \\
\text { - } \text { Altered mental status } \\
\text { - } \text { Focal neurological deficit } \\
\text { - } \text { History of psychiatric illness } \\
\text { - } \text { Heart rate }<50 \text { BPM or }>150 \text { beats per minute } \\
\text { - } \text { Respiratory rate }<8 \text { or }>30 \text { breaths per minute } \\
\text { - } \text { Allergy to any studied agent or ingredient } \\
\text { - History of drug use } \\
\text { - } \text { Alcohol abuse glaucoma } \\
\text { - Intracranial hypertension } \\
\text { - Ischemic heart disease } \\
\text { - HIV } \\
\text { - Immunosuppression } \\
\text { - } \text { Renal disease requiring dialysis } \\
\text { - } \text { Liver disease } \\
\text { - } \text { Poorly controlled thyroid disease } \\
\text { - Active bleeding or current use of anticoagulants }\end{array}$ \\
\hline $\begin{array}{l}\text { Afridi et al } \\
(2013)^{25}\end{array}$ & $\begin{array}{l}\text { - History of aura du- } \\
\text { rations of } \geq 3 \text { hours } \\
\text { - Progression of aura } \\
\text { from onset to }\end{array}$ & $\begin{array}{l}\text { - } \text { Pregnant women } \\
\text { - History of asthma } \\
\text { - History of psychiatric disorders } \\
\text { - History of cardiac disorders }\end{array}$ \\
\hline
\end{tabular}




\begin{tabular}{|l|l|l|}
\hline maximal disability & \\
to be greater than 10 & \\
minutes & \\
\hline
\end{tabular}

